\title{
Butterfly monitoring using systematically placed transects in contrasting climatic regions - exploring an established spatial design for sampling
}

\author{
Elin Videvall', Erik Öckinger ${ }^{2}$, Lars B. Pettersson ${ }^{1,3}$
}

I Lund University, Department of Biology, Ecology Building, 22362 Lund, Sweden 2 Swedish University of Agricultural Sciences, Department of Ecology, PO Box 7044, 75007 Uppsala, Sweden 3 Swedish Butterfly Monitoring Scheme, Ecology Building, SE-223 62 Lund, Sweden

Corresponding author: Lars B. Pettersson (lars.pettersson@biol.lu.se)

Academic editor: R. Julliard | Received 13 December 2015 | Accepted 3 March 2016 | Published 13 April 2016

http://zoobank.org/E60AC4D4-OE14-4272-80AF-E8001D3D8590

Citation: Videvall E, Öckinger E, Pettersson LB (2016) Butterfly monitoring using systematically placed transects in contrasting climatic regions - exploring an established spatial design for sampling. Nature Conservation 14: 41-62. doi: 10.3897/natureconservation.14.7497

\begin{abstract}
Butterfly monitoring schemes are recording programs initiated to monitor nationwide butterfly abundance and distribution patterns, often with help from volunteers. The method generates high-resolution data, but may be associated with a degree of habitat sampling bias if volunteers prefer to survey areas perceived to be high-quality butterfly habitats. This can result in habitats becoming underrepresented in the data set, leading to less information about the butterfly populations there. In the present study, we investigate the possibility of applying a spatial design used by the Swedish Bird Survey for nationwide, gridbased sampling, with a goal to get butterfly monitoring data covering a representative sample of different habitats. We surveyed four $2 \times 2 \mathrm{~km}$ sampling squares, split into $100 \mathrm{~m}$ segments, in the southernmost region of Sweden (Scania) and four in the northernmost region (Norrbotten). The grid-based transects were compared with volunteer-selected transects in a GIS analysis using a refined Swedish version of CORINE land cover data to see how well these two transect designs represent true habitat coverage. A total of $53 \mathrm{~km}$ transect was monitored, resulting in 490 individuals and 29 different species recorded. We found that transect cover correlated significantly with overall land cover using both monitoring methods, though standardised transects outperformed volunteer-selected transects in habitat representation in Scania, but not in Norrbotten. Butterflies were found to aggregate significantly in specific habitats, but with contrasting results for the two geographically different regions. Grasslands in both regions generated a high number of recorded butterflies, although so did clear-cut and residential areas in Norrbotten as well. The
\end{abstract}

Copyright Elin Videvall et al. This is an open access article distributed under the terms of the Creative Commons Attribution License (CC BY 4.0), which permits unrestricted use, distribution, and reproduction in any medium, provided the original author and source are credited. 
highest number of individuals recorded per transect was found in bogs in Scania. This study emphasises the value of complementing free site selection monitoring schemes with spatially representative schemes such as the Swedish Bird Survey, and sheds some light on general habitat preferences for Swedish butterflies in two contrasting climatic regions.

\section{Keywords}

Butterflies, monitoring, biodiversity, habitat, sampling, transects, boreal, continental, populations, GIS, CORINE

\section{Introduction}

Butterflies are the most widely studied of all insect groups (Dennis et al. 2006, van Swaay et al. 2008), and their sensitivity to environmental change together with the availability of butterfly data makes this group very useful as indicators for biodiversity (New 1997, Thomas 2005, Dennis et al. 2006, van Swaay et al. 2015). Furthermore, since many butterfly species require a warm microclimate for optimal growth and development (Wallisdevries and Van Swaay 2006, Eilers et al. 2013), they can also serve as indicators for climatic change (Thomas 2005, van Swaay et al. 2008, Betzholtz et al. 2013). While birds, another popular group of biodiversity indicators, range more widely and over larger areas, butterflies provide important additional and complementary area-specific information since they are more likely to reflect environmental changes occurring on a more detailed scale (van Swaay et al. 2006).

Habitat loss and fragmentation is a major driver behind the decline of many butterfly species worldwide (Bergman et al. 2004, Ekroos et al. 2010). Due to changes in land-use and intensification of agriculture throughout the last century there has been a loss of many open and half-open natural and semi-natural habitats (Nilsson et al. 2013, Cousins et al. 2015). This has had dramatic effects on many insect groups, and there has been a decline in butterfly numbers all over Europe (van Swaay et al. 2006, Konvicka et al. 2008, Van Dyck et al. 2009, Dover et al. 2011). The recently developed "European Grassland Butterfly Indicator" (van Swaay et al. 2015) based on butterfly data from 22 European countries suggests that grassland butterfly populations may have declined as much as 30\% since 1990 .

In order to effectively monitor population trends, butterfly monitoring schemes now run in several European countries, e.g. the UK, Finland, Germany and the Netherlands (van Swaay et al. 2008, 2015, Kühn et al. 2012, Botham et al. 2013, Heliölä et al. 2013). Schemes vary in the way monitoring sites are selected (van Swaay et al. 2015), with some schemes using random site placement whereas others have sites selected by coordinators. However, the majority of schemes use the more flexible approach where butterfly recorders can place their monitoring sites freely (van Swaay and Warren 2012, van Swaay et al. 2015). Free site selection is generally appreciated by recorders as they can be involved in the site selection process by influencing choice of site characteristics, accessibility, and being able to relate more closely to the sites that they monitor (van Swaay and Warren 2012). The main disadvantage of free site 
selection is that the geographic coverage commonly becomes non-random and hence not representative of habitats and butterfly populations in general (Dover et al. 1997, van Swaay and Warren 2012, van Swaay et al. 2015). The concern that open areas and in particular semi-natural grasslands tend to become overrepresented in monitoring data and that forests and other parts of the wider countryside are less well covered (van Swaay and Warren 2012) have recently inspired strategies that substantially reduce sampling bias (e.g, Brereton et al. 2011, Lang and Buhler 2012).

In the UK, species that are widespread across the general countryside compromise half of the butterfly fauna (Asher et al. 2001) but are underrepresented in traditional monitoring; declines for these species went largely undetected by monitoring schemes during the $20^{\text {th }}$ century (Brereton et al. 2011). This led to the launch of the Wider Countryside Butterfly Survey, a scheme which uses the grid-based sampling design of the British Bird Survey (Greenwood et al. 1995) to get representative trends across the whole countryside (Brereton et al. 2011, Botham et al. 2013, Roy et al. 2015). Grid-based, spatially representative sampling is increasingly used in bird monitoring today (e.g, Greenwood et al. 1995, Davey et al. 2013, Lehikoinen 2013) and offers an attractive development for butterfly monitoring (Kéry and Plattner 2007, Brereton et al. 2011, Lang and Buhler 2012, van Swaay and Warren 2012). However, there is a great need to evaluate how well such standardised designs suit butterfly monitoring in different climatic regions. Factors such as the openness of the countryside, topography, and the time and effort necessary to walk transects in different regions can differ markedly even within one single country (Brereton et al. 2011) and is particularly relevant in countries that span a large range of latitudes. For instance, a coniferous forest in Sweden's southern, continental region can be dense, dark and not particularly well suited for butterflies. In contrast, corresponding forests in the northern, boreal region can be much more open, sunlit, and hence attractive to butterflies.

The Swedish Butterfly Monitoring Scheme is a nationwide program with free site selection (Pettersson et al. 2011). Volunteers appreciate that they can place monitoring transects themselves and this flexible design has been central to the growth of the scheme. Because free site selection tends to result in some habitats being underrepresented (van Swaay and Warren 2012), it would be valuable to complement the Swedish scheme with a grid-based approach (cf. Lindenmayer and Likens 2009). A very promising way of doing so would be to count butterflies along transects that already form part of a standardised, nationwide monitoring design: the Swedish Bird Survey (Green and Lindström 2015). This scheme consists of 716 routes in a $25 \times 25$ $\mathrm{km}$ grid, covering Sweden as a whole. The layout ensures that all major habitats are proportionally represented. At the centre of each grid cell, the bird fauna is censused once per year along eight $1 \mathrm{~km}$ transects arranged in a $2 \times 2 \mathrm{~km}$ square (Figure 1, Green and Lindström 2015). The standard method of butterfly monitoring, using "Pollard walk" transects, (Pollard and Yates 1993) could potentially be used along the bird monitoring transects (Brereton et al. 2011, Roy et al. 2015). Hence, the grid used by the Swedish Bird Survey offers an attractive design for obtaining butterfly monitoring data that cover major habitats proportionately. 
With this study we have a twofold goal. The first is to evaluate if the large-scale, grid-based method used by the Swedish Bird Survey can be adapted and applied to butterfly monitoring. The second aim is to use the collected data to quantify butterfly abundance in relation to habitat characteristics in two contrasting climatic regions of Sweden: Scania and Norrbotten.

\section{Methods}

\section{GIS analysis of land cover}

While transects based on standardised grid-based designs are generally assumed to outperform free site selection in terms of true habitat representation, this assumption is rarely evaluated. Here, we quantified land cover in the Swedish Bird Survey transects visited in the present experiment ( $N=4$ in each region, total length: $32 \mathrm{~km}$ per region) as well as land cover in volunteer-selected free transects in the same regions $(N=5$ in each region, total length $12.92 \mathrm{~km}$ in Scania and $12.22 \mathrm{~km}$ in Norrbotten). The free transects that were analysed comprised all sites in Norrbotten and a random, corresponding subsample of the transects in Scania. The free transects that we analysed covered less distance that the standardised transects and hence had smaller areas. To allow direct comparison despite differing total areas, we recalculated land cover to the smallest area (free transects, Scania: $4.45 \mathrm{~km}^{2}$; Appendix: Table S3). Land cover data was obtained from the SMD database, which is a refined, Swedish version of the CORINE land cover database with the smallest mapping unit 1-25 ha, map resolution $25 \times 25 \mathrm{~m}$, and 2000 as reference year (Swedish Environmental Protection Agency, 2014). To quantify land cover class coverage, we clipped the SMD using a $200 \mathrm{~m}$ buffer around each transect following Davey et al. (2013) using QGIS (v.2.12, QGIS Development Team 2016).

\section{Field data collection}

Butterfly monitoring took place during the summer of 2010 from June 17 to July 7 in Scania, the southernmost part of Sweden, and from July 20-28 in Norrbotten, the northernmost part of Sweden. Each site consisted of the four outer sections of $2 \times 2 \mathrm{~km}$ squares used by the Swedish Bird Survey (Figure 1), equalling an $8 \mathrm{~km}$ long transect. The survey squares were selected with the intention to cover different habitats along the transects, in order to thoroughly test the sampling method. The four sites visited in Scania were called Hyby, Tjörnarp, Slätteberga and Kongaö, and the four sites in Norrbotten were Sundom, Rosfors, Långberget and Bergnäset (Appendix: Table S1, Figure 1). Two persons (EV together with a colleague) walked all transects. Recording only took place during sunny weather, and monitoring did not start earlier than $10 \mathrm{am}$ and ended not later than $5 \mathrm{pm}$ (Central European summer time, UTC +2), which is the time most suitable for butterfly activity (van Swaay et al. 2008). Average tempera- 


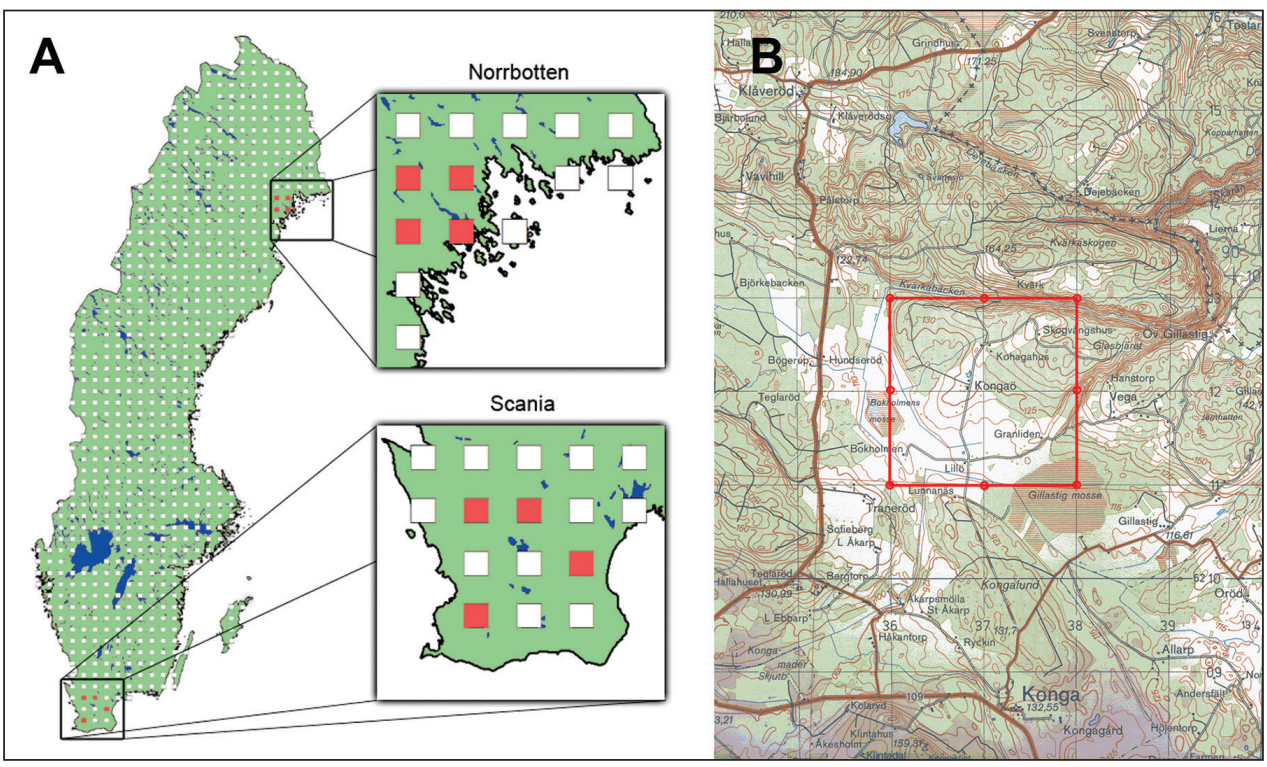

Figure I. A Map over Sweden with systematically placed bird monitoring squares throughout the country, used by the Swedish Bird Survey. The two regions featured in this study are shown, with monitoring squares visited portrayed in red. The squares are $2 \times 2 \mathrm{~km}$ wide, indicate location, and not shown to scale B Example map of a bird monitoring square: site Kongaö in Scania, Sweden, indicated as a red, $2 \times 2 \mathrm{~km}$ square. Butterfly transects followed the periphery of bird monitoring squares $(N=8$ sites) as closely as possible for as long as weather conditions and time of day permitted (Pettersson et al. 2011). Lantmäteriet, I2014/00579.

ture throughout the day ranged from $17{ }^{\circ} \mathrm{C}$ to $25^{\circ} \mathrm{C}$, and the wind varied in different habitats, but never exceeded 5 in the Beaufort scale, which is acceptable in terms of butterfly monitoring (van Swaay et al. 2008).

All transects monitored were divided into segments of approximate $100 \mathrm{~m}$ length with an accompanying description for the habitat surrounding the transects. The distance of the transect segments were estimated with the help of maps. The different habitat categories were: deciduous forest, coniferous forest, grassland, residential area, fen/ bog, and clear-cut area (examples of three habitats can be seen in Figure 2). Road was added as an additional unique category since much monitoring had to be performed on small paths and roads due to accessibility. The habitat description of each $100 \mathrm{~m}$ segment consisted of percentages of each habitat category that the transect crossed (e.g. deciduous forest $80 \%$, grassland $20 \%$ ), in order to reflect the surroundings as closely as possible. As each butterfly individual was attributed to a specific $100 \mathrm{~m}$ segment, this typically resulted in non-integer numbers for butterfly individual and species counts per habitat category (i.e. 0.8 butterflies in deciduous forest and 0.2 butterflies in grassland, based on the example above). Areas such as cultivated fields, highly dense forests and open water were avoided for reasons of safety, land-owner privacy, and accessibility.

Recordings were made of all butterflies (Rhopalocera) and burnet moths (Zygaenidae), as seen within an 'invisible box' of $5 \mathrm{~m}$ in front of the recorders, $2.5 \mathrm{~m}$ to each side 

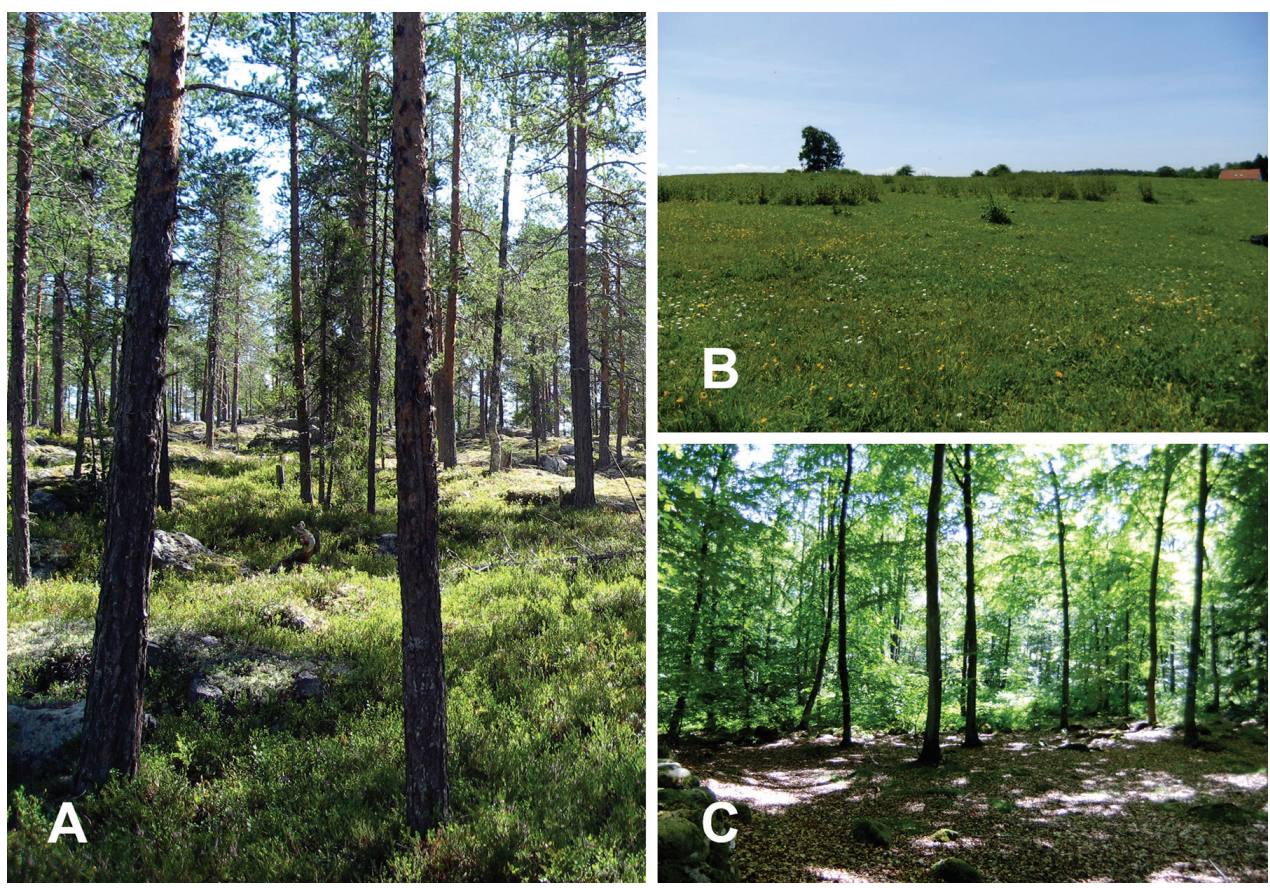

Figure 2. Examples of butterfly habitat categories: A coniferous forest in Rosfors (Norrbotten) B grassland in Hyby (Scania), and $\mathbf{C}$ deciduous forest in Slätteberga (Scania). Photos by Elin Videvall.

and $5 \mathrm{~m}$ above, according to the 'Pollard walk' method (Pollard and Yates 1993, Pettersson et al. 2011). The monitoring was paused during the time for identification of the species, and subsequently resumed. Observations were documented using a butterfly net and a camera, and validated to species level using colleagues and literature (Eliasson et al. 2005, Söderström 2006). The pace of walking depended on habitat, accessibility, and butterfly density, but was in general approximately $3 \mathrm{~km} / \mathrm{h}$. Double counting of individuals cannot be completely ruled out, but was avoided as far as possible. Individuals not caught and identified to species level were counted and included in the (total) butterfly abundance analyses but not in any species or biodiversity measurements. In total, 42 out of 490 individuals observed (8.6\%) could not be identified to species level (Appendix: Table S2). Recorder bias should not be of major concern since one of the authors (EV) was present at all sites and single-handedly documented each individual recorded. Species names (English and scientific) follow Tolman (2001) and Eliasson et al. (2005), respectively.

\section{Data analyses}

For each region, we evaluated similarity in habitat coverage between the region as a whole and the two transect approaches using Spearman Rank Correlation tests within 
each region followed by two-sample tests of correlation coefficients using Fisher ztransformed values (Zar 1999).

Butterfly data was compiled using values per $100 \mathrm{~m}$ segment as the basis for calculations. To quantify biodiversity, we used the Simpson's Diversity Index (Magurran 2004), where both the number of species as well as the abundance of the species is taken into account. The Simpson's Index $(D)$ measures the probability that two individuals randomly selected from a sample will belong to the same species,

$$
D=\sum_{i=1}^{S} \frac{n_{i}\left(n_{i}-1\right)}{N(N-1)}
$$

where $n_{i}=$ the number of individuals in the $i$ th species, $N=$ the total number of individuals and $S=$ the number of species in the sample. We represent this biodiversity measurement as $1 / D$, called the Simpson's Reciprocal Index. In this variant of $D, 1$ is the lowest possible value, representing a community containing only one species, and the maximum possible value is the number of species in the sample (Magurran 2004). Further, we used the Simpson's Evenness Index (1/DS) representing the species evenness in sites with values ranging from 0 (aggregation of species) to 1 (completely even; Magurran 2004).

Alpha $(\alpha)$ diversity generally measures species diversity of a defined area or habitat, whereas beta $(\beta)$ diversity is used as a measure of the difference between two or more defined areas (Magurran 2004, Anderson et al. 2011). Following this, we use the term $\alpha$ diversity for the site-specific diversity measure (number of species per site), and $\beta$ diversity for the difference between the number of species at each site and the number of species in the region). Each diversity measure results in four replicates per region. In order to assess whether $\alpha$ and $\beta$ diversity differed between regions, we used a Wilcoxon two-sample test.

Chi-square tests of butterfly abundance were performed for each habitat category, to test if butterfly distributions differed from random expectations, i.e. if individuals distributed among habitat categories according to their relative coverage along the transects. All statistical analyses were performed in R (v. 2.15, R Core Team 2013).

\section{Results}

\section{GIS land cover analysis}

The land cover representation of the Swedish Bird Survey transects and the volunteerselected transects correlated significantly with overall land cover within Scania (SMD land cover classes: SBS transects: $\mathrm{r}=0.890, N=14, p<0.001$; in free transects: $\mathrm{r}=$ $0.524, N=16, p=0.04$, Appendix: Table S3) as well as in Norrbotten (SMD land cover classes: SBS transects: $\mathrm{r}=0.733, N=20, p<0.001$; free transects: $\mathrm{r}=0.422, N$ $=23, p=0.045$, Appendix: Table S3). In Scania, the correlation between overall land 
cover and Swedish Bird Survey transects was significantly higher than that between overall land cover and free selection transects $(Z=2.054, p=0.03)$. There was no difference in the relation between overall land cover and the two transect categories in Norrbotten $(Z=1.472, p=0.14)$.

\section{Use of bird monitoring squares}

The systematically placed $2 \times 2 \mathrm{~km}$ squares used by the Swedish Bird Survey correspond to $8 \mathrm{~km}$ butterfly transect per site ( 80 segments). In total we monitored $53 \mathrm{~km}$ transect $(83 \%)$ out of the $64 \mathrm{~km}$ transect present in the eight squares combined. Using transects along the borders of Bird Survey squares proved to be slightly more than what was normally possible to cover within one day of butterfly recording. The landscape along the transects was sometimes difficult to traverse, and some parts of the transects were completely inaccessible. The overall distance monitored in the two regions was very similar, with $27 \mathrm{~km}$ in Scania and $26 \mathrm{~km}$ in Norrbotten. Even though some of the squares were not completely surveyed, we got a substantial amount of data with an average of $6.6 \mathrm{~km}$ transect monitored per site.

\section{Habitat coverage in the two regions}

Field estimates of total habitat coverage was divided fairly equal between deciduous forest $(25 \%)$, coniferous forest (26\%), and grassland (30\%), among all transects monitored (Figure 3 ). The remaining three habitat categories had less coverage, with clearcut area at $4 \%$, residential area had $9 \%$, and fen/bog covered $6 \%$ of all transects. A large part $(39 \%)$ of all monitoring was performed alongside smaller roads or paths. Scania had a higher percentage of deciduous forest while the dominant habitat in Norrbotten was coniferous forest (Figure 3).

\section{Butterfly monitoring}

A total of 490 butterfly individuals were recorded, with 250 counted in Scania (9.3 individuals per $\mathrm{km}$ transect) and 240 in Norrbotten (9.2 individuals per $\mathrm{km}$ transect). We recorded 29 different butterfly species (Appendix: Table S2), but no burnet moths. We found 22 species in Scania and 16 species in Norrbotten. Of the 22 species recorded in Scania, 13 were uniquely found in this region, and in Norrbotten, 6 out of 16 species were only found in this region. The site with the highest number of species recorded was Långberget in Norrbotten with 12 different species, whereas Kongaö in Scania was the site with most individual recordings (147 individuals) (Appendix: Table S1). 

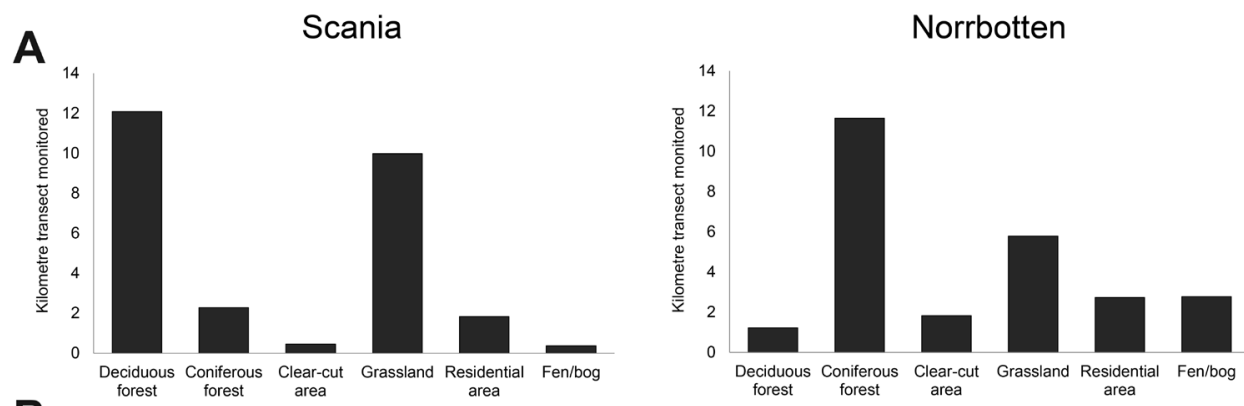

B
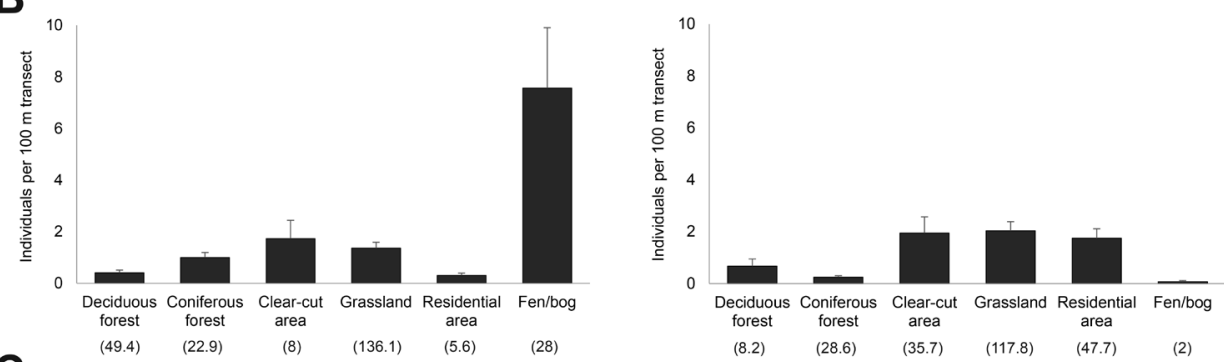

C
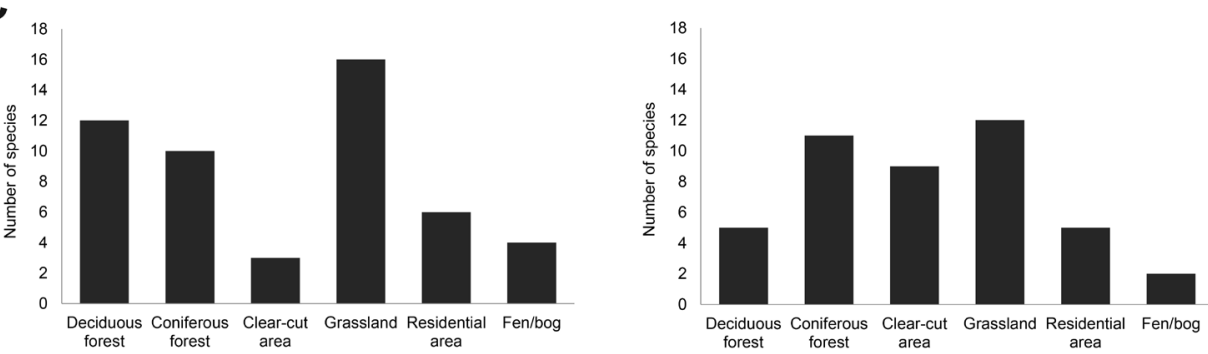

Figure 3. A Transect monitored $(\mathrm{km})$ in different habitats for two geographically different regions in Sweden: the southernmost region, Scania, and the northernmost region, Norrbotten B Number of butterfly individuals recorded per $100 \mathrm{~m}$ transect in different habitats (mean values $\pm \mathrm{SE}$ ). Numbers in parentheses indicate total number of individuals monitored per habitat (non-integers due to proportional habitat coverage per $100 \mathrm{~m}$ transect) C Total number of butterfly species recorded in the different habitats.

\section{Butterfly abundance in different habitats}

Butterfly abundance in different habitats was compared to the expected number of individuals relative to habitat coverage in each region (Table 1 and Figure 3). Within the habitat category deciduous forest, a significantly lower number of individuals was observed in the region of Scania than expected if the butterflies had distributed randomly over the transects $\left(\chi^{2}=24.2, p<0.001\right)$ (Table 1$)$, but they were not relatively fewer than expected in the deciduous forests of Norrbotten $\left(\chi^{2}=0.48, p=0.488\right)$. The opposite was true for coniferous forests: in Norrbotten we observed significantly fewer individuals than expected $\left(\chi^{2}=45.8, p<0.001\right)$, but in Scania the number of 
Table I. Butterfly abundance in different habitats for two geographically different Swedish regions, Scania and Norrbotten.

\begin{tabular}{c|c|c|c|c|c|c}
\hline & $\begin{array}{c}\text { Number of } \\
\text { individuals } \\
\text { recorded }\end{array}$ & $\begin{array}{c}\text { Mean nr of } \\
\text { individuals } \\
\text { per 100 } \mathbf{~ m}\end{array}$ & $\chi^{2}$-value & p-value & Significance $\mathbf{1}^{1}$ & $\begin{array}{c}\text { Abundance relative } \\
\text { to expected value }\end{array}$ \\
\hline Scania & & & & & & \\
\hline Deciduous forest & 49.4 & 0.4 & 24.2 & $<0.001$ & $* * *$ & Lower \\
\hline Coniferous forest & 22.9 & 1.0 & 0.07 & 0.787 & ns & No difference \\
\hline Clear-cut area & 8.0 & 1.7 & 1.1 & 0.286 & ns & No difference \\
\hline Grassland & 136.1 & 1.4 & 8.4 & 0.004 & $* *$ & Higher \\
\hline Residential area & 5.6 & 0.3 & 5.7 & 0.017 & $*$ & Lower \\
\hline Fen/bog & 28.0 & 7.6 & 19.2 & $<0.001$ & $* * *$ & Higher \\
\hline Norrbotten & & & & & & \\
\hline Deciduous forest & 8.2 & 0.7 & 0.48 & 0.488 & ns & No difference \\
\hline Coniferous forest & 28.6 & 0.3 & 45.8 & $<0.001$ & $* * *$ & Lower \\
\hline Clear-cut area & 35.7 & 2.0 & 6.7 & 0.009 & ${ }^{* *}$ & Higher \\
\hline Grassland & 117.8 & 2.0 & 24.2 & $<0.001$ & ${ }^{* * *}$ & Higher \\
\hline Residential area & 47.7 & 1.8 & 6.9 & 0.008 & $* *$ & Higher \\
\hline Fen/bog & 2.0 & 0.07 & 20.2 & $<0.001$ & $* * *$ & Lower \\
\hline
\end{tabular}

${ }^{1}$ Chi-square tests between observed and expected number of individuals indicate significant differences in habitats denoted with asterisks: ns (non-significant), ${ }^{*}(p<0.05),{ }^{* *}(p<0.01)$, and ${ }^{* * *}(p<0.001)$.

individuals recorded in this habitat matched the expected number very well $\left(\chi^{2}=0.07\right.$, $p=0.787)$. The habitat category fen/bog inhabited significantly more individuals than expected in Scania $\left(\chi^{2}=19.2, p<0.001\right)$, but significantly fewer individuals in Norrbotten $\left(\chi^{2}=20.2, p<0.001\right)$ (Table 1 and Figure 3$)$.

In Norrbotten, we found a significantly higher number of individuals in clear-cut areas $\left(\chi^{2}=6.73, p=0.009\right)$ and in residential areas $\left(\chi^{2}=6.94, p=0.008\right)$ than expected, but not in the clear-cut areas of Scania $\left(\chi^{2}=1.14, p=0.286\right)$, and in Scania's residential areas we even recorded significantly fewer individuals than expected $\left(\chi^{2}=\right.$ $5.71, p=0.017$ ) (Table 1). Not surprisingly, significantly more individuals were found in grasslands than expected, in both Scania $\left(\chi^{2}=8.35, p=0.004\right)$ and Norrbotten $\left(\chi^{2}\right.$ $=24.2, p<0.001$ ) (Figure 3 ), though the aggregation of butterflies in grasslands were denser in Norrbotten.

\section{Butterfly species richness in different habitats}

The habitat with highest number of species recorded in total was grassland, with 16 different species recorded in Scania and 12 species in Norrbotten, however this might be partly due to relatively high coverage of grassland monitored, with $10 \mathrm{~km}$ grassland visited in Scania (37\%), and $5.8 \mathrm{~km}$ in Norrbotten (22.3\%) (Figure 3). Nonetheless, grassland displayed significantly higher number of species in Norrbotten than expected $\left(N=12, \chi^{2}=4.58, p=0.032\right.$; Table 2). Despite lower habitat coverage of coniferous 
Table 2. Species richness in different habitats in two geographically different Swedish regions, Scania and Norrbotten.

\begin{tabular}{c|c|c|c|c|c}
\hline & $\begin{array}{c}\text { Number of species } \\
\text { recorded }^{1}\end{array}$ & $\chi^{2}$-value & $\boldsymbol{p}$-value & Significance $^{2}$ & $\begin{array}{c}\text { Diversity relative } \\
\text { to expected value }\end{array}$ \\
\hline Scania & & & & & \\
\hline Deciduous forest & 12 & 0.21 & 0.644 & $\mathrm{~ns}$ & No difference \\
\hline Coniferous forest & 10 & 5.59 & 0.018 & $*$ & Higher \\
\hline Clear-cut area & 3 & 2.05 & 0.152 & $\mathrm{~ns}$ & No difference \\
\hline Grassland & 16 & 2.57 & 0.109 & $\mathrm{~ns}$ & No difference \\
\hline Residential area & 6 & 2.72 & 0.099 & $\mathrm{~ns}$ & No difference \\
\hline Fen/bog & 4 & 3.18 & 0.074 & $\mathrm{~ns}$ & No difference \\
\hline Norrbotten & & & & & \\
\hline Deciduous forest & 5 & 3.14 & 0.076 & $\mathrm{~ns}$ & No difference \\
\hline Coniferous forest & 11 & 0.81 & 0.369 & $\mathrm{~ns}$ & No difference \\
\hline Clear-cut area & 9 & 6.11 & 0.013 & $*$ & Higher \\
\hline Grassland & 12 & 4.58 & 0.032 & $*$ & Higher \\
\hline Residential area & 5 & 1.65 & 0.199 & $\mathrm{~ns}$ & No difference \\
\hline Fen/bog & 2 & 0.02 & 0.880 & $\mathrm{~ns}$ & No difference \\
\hline
\end{tabular}

${ }^{1}$ Excluding unidentified species, see Appendix: Table S2,

${ }^{2}$ Chi-square tests between observed and expected number of species indicate significant differences in habitats denoted with asterisks: ns (non-significant), ${ }^{*}(p<0.05)$.

forests and fens/bogs in Scania, these habitats still harboured several butterfly species ( $N=10$ and $N=4$, respectively). The same was true for Norrbotten's clear-cut areas and deciduous forests ( $N=9$ and $N=5$, respectively; Figure 3 and Table 2). The habitat with the lowest species diversity, despite moderate habitat coverage, was fens/bogs in Norrbotten $(N=2$, Figure 3).

\section{Biodiversity measures}

The biodiversity in the two regions was measured using the Simpson Reciprocal Diversity Index $(1 / D)$ and the Simpson Evenness Index (1/DS). The Simpson Reciprocal Index for Scania (6.86) was slightly higher (although non-significantly) than the index for Norrbotten (5.10) (this difference was tested between the sites using a Wilcoxon rank sum test: $\mathrm{W}=12, p=0.31$ ). The Simpson Evenness Index for Scania (0.31), was similar and not significantly different than the corresponding number for Norrbotten (0.32) (tested between the sites with a Wilcoxon rank sum test: $\mathrm{W}=11, p=0.47$ ).

The mean species number within a region, the $\alpha$ diversity, did not differ significantly between Scania and Norrbotten (Wilcoxon rank sum test: $\mathrm{W}=10, p=0.661$ ). The $\beta$ diversity, defined here as the mean difference in species number between each site and the total species number of that region, was significantly higher in Scania than in Norrbotten (Wilcoxon rank sum test: $\mathrm{W}=16, p=0.028$ ). 


\section{Discussion}

\section{Butterfly recording using systematically placed transects}

In this study we have tested the possibility of using systematically placed transects in butterfly monitoring schemes in order to get butterfly recordings with reduced volunteer habitat bias. Volunteer recorders are most often free to select the location for monitoring (Roy et al. 2007, van Swaay et al. 2008), which may result in taxonomically and geographically biased records. Dennis and Thomas (2000) and Dennis et al. (1999) demonstrated that species richness and occurrence are positively correlated with recording intensity. The volunteers' visits are biased by access (e.g. the distance from their home), the location of potential 'butterfly hot spots' (either diversity or rarity hot spots), and areas with a greater number of butterfly resources (such as seminatural grasslands). This type of bias allows for good coverage of environmentally protected sites but may not provide trends representative for species in other habitats (e.g. woodland species, Roy et al. 2007).

Our GIS analyses showed that standardised transects mirrored overall land cover better than free transects in Scania, but not significantly better in Norrbotten. The Norrbotten landscape is generally less urbanised than Scania (cf. Appendix: Table S3), and one likely explanation that free transects do not represent true habitat coverage as well in Scania is that such transects are more likely to be placed near where volunteers live (cf. Dennis and Thomas 2000; Pettersson et al. 2011) and human influence on adjacent habitats is more pronounced in Scania than in Norrbotten. This is true not only for the extent of urban structures but also for semi-natural grasslands and other habitats heavily influenced by human activities.

We found that the transects used by the Swedish Bird Survey provided good coverage of traditionally underrepresented butterfly habitats such as forests, clear-cuts and wetlands in both regions (Figure 3, cf. Brereton et al. 2011, Roy et al. 2015). Even though the habitat categorisation was broad, our results clearly indicate that there are several habitats other than grasslands harbouring butterflies. Similarly, Berg et al. (2011) demonstrated that several typically overlooked habitats in forest-dominated landscapes can have at least as high numbers of butterfly species as semi-natural grasslands. Thus, it is evident that systematically placed transects throughout the country can be an important consideration in order to reduce bias in habitat coverage. It is highly likely that some of the habitats monitored, such as deciduous and coniferous forests, are strongly underrepresented in traditional butterfly monitoring.

During the year that the present study was performed, there were still relatively few free transects in Scania and Norrbotten and a direct comparison of simultaneously collected butterfly recordings from multiple standardized and free transects was not possible. Now substantially more free transects are monitored and such a direct comparison of observations made throughout the season would be a logical next step. 


\section{Butterfly abundance and species richness in different habitats}

We found major differences in butterfly abundance and species richness in the different habitats and between the two regions. In grasslands, we found more butterfly individuals than expected in both regions (Table 1), and the total number of species found was the highest in this habitat, for both regions (Table 2). Although grassland was also the second most monitored habitat in terms of total transect length for both regions (Figure 3), the number of species recorded per $100 \mathrm{~m}$ transect was still relatively high, and our results confirm the importance of grassland habitats for both butterfly abundance and species richness.

The clear-cut and residential areas in Norrbotten harboured more butterfly individuals than expected, but not in Scania; this region had instead significantly fewer individuals recorded in residential areas (Table 1). For the two forest habitat categories, we found fewer individuals in deciduous forests in Scania (but not in Norrbotten), and fewer individuals in coniferous forests in Norrbotten (but not in Scania) (Table 1). The contrasting differences between the regions in butterfly abundance in different habitats may be due to the drastic latitudinal and climatic differences of the two regions. Interestingly, we recorded significantly more individuals and species than expected in the habitat fen/bog in Scania, where a relatively small area harboured a substantial number of Cranberry Blues (Plebeius optilete), but also other species. These results stress the value of using representative, grid-based geographic sampling so that diversity hotspots and common habitats become neither over- nor underrepresented in monitoring schemes.

The $\beta$ diversity was significantly different between the regions Scania and Norrbotten, indicating that the sites in Norrbotten harboured many of the same species, as opposed to Scania where the sites often had different species composition. This is most likely because Norrbotten has a smaller species pool compared to Scania, which harbours several rare and local butterfly species (Eliasson et al. 2005, Öckinger et al. 2006). Alternatively, the $2 \times 2 \mathrm{~km}$ squares in Norrbotten could be more similar to each other in terms of habitat composition compared to the Scanian study squares.

Some butterfly species that we recorded in Scania were not seen in Norrbotten $(N=13)$, and in Norrbotten 6 out of 16 species were not found in Scania. This is likely due to the climate differences resulting in different species distributions, but it is also plausible that many species were not detected by chance. We monitored the two regions intentionally during different dates to take into account their differences in spring arrival. Recordings in Scania were performed between June $17^{\text {th }}$ and July $7^{\text {th }}$, and recordings in Norrbotten in late July $\left(20^{\text {th }}-28^{\text {th }}\right)$. Because of the large latitudinal differences between the regions (Appendix: Table S1), spring can arrive approximately seven weeks later in Norrbotten than in Scania (Alexandersson 2002), so we believe the later monitoring in Norrbotten would take most of this into account. 


\section{Implications for future butterfly monitoring}

A 'reduced effort' monitoring scheme is based on a higher number of transects and counted only a few times per year, as opposed to the more traditional scheme, which are to a greater extent based on more regular visits and free site selection (van Swaay et al. 2008). A reduced effort scheme with fewer visits per year but more sites monitored might make volunteers more willing to record in areas where they are less likely to record high numbers of individuals or many species (Roy et al. 2007). Stratified random sampling of sites or systematically placed sites (like in this study), will generate a lot of data for widespread butterfly species but fewer records of rare or localised species (van Swaay et al. 2008). This can, however, be mitigated by adding additional transects at sites where these species are known to occur (van Swaay et al. 2008, van Swaay and Warren 2012).

A Swedish butterfly monitoring scheme with systematically placed transects throughout the country with the intention to cover different habitats would produce a representative picture of the nation's butterfly population without introducing bias from habitat choice by the recorder. Free and systematic site selection should however not be seen as mutually exclusive. The Swedish Bird Survey started with free site selection in 1969 and added its grid-based network of geographically representative transects to the monitoring scheme in 1996. Similarly, the UK butterfly monitoring scheme has added a complementary, Wider Countryside monitoring scheme (Brereton et al. 2011, Roy et al. 2015). In other words, free selection transects and geographically representative ones can certainly exist side by side. In fact, grid networks encouraging spatially representative selection of free sites are used by some monitoring schemes (e.g. Åström et al. 2014).

Following this, we suggest that it would be valuable to complement monitoring schemes with free site selection such as the Swedish butterfly monitoring by adding standardised, grid-based sampling schemes. An exciting possibility resulting from joint monitoring of different organisms in a grid-based design is that more general biodiversity trends such as those indicated by Thomas et al. (2004) could be addressed at high spatial resolution. In general, we believe that transects for recording butterflies need to be smaller than the $2 \times 2 \mathrm{~km}$ squares used by the Swedish Bird Survey. If national butterfly monitoring relies on recordings by volunteers, the transect cannot be too long as it might deter volunteers from participating. Monitoring squares the size of $1 \times 1 \mathrm{~km}$ or $750 \times 750 \mathrm{~m}$, as used in study by Jonason et al. (2010), is a much more reasonable size for a butterfly monitoring scheme.

\section{Acknowledgements}

We would like to thank the co-recorders participating in this study: Elisabeth Arvidsson for monitoring assistance in Scania, Anneli Sandström and Daniel Moberg for monitoring assistance in Norrbotten. We are also grateful to The Entomological Society of Lund (ESIL) for funding EV with materials used in this study, and to Åke Lindström 
and Martin Stjernman for providing the Swedish Bird Survey maps. Tobias Roth acted as reviewer for this manuscript and provided valuable comments on a previous version. LP is funded by the Swedish Environmental Protection Agency as part of the Swedish Butterfly Monitoring Scheme.

\section{References}

Alexandersson H (2002) Temperatur och nederbörd i Sverige 1860 -2001. SMHI Meteorologi 104. SMHI, Norrköping.

Anderson MJ, Crist TO, Chase JM, Vellend M, Inouye BD, Freestone AL, Sanders NJ, Cornell HV, Comita LS, Davies KF, Harrison SP, Kraft NJ, Stegen JC, Swenson NG (2011) Navigating the multiple meanings of beta diversity: a roadmap for the practicing ecologist. Ecology Letters 14: 19-28. doi: 10.1111/j.1461-0248.2010.01552.x

Asher J, Warren MS, Fox R, Harding P, Jeffcoate G, Jeffcoate S (2001) The millennium atlas of butterflies in Britain and Ireland. Oxford University Press, Oxford.

Åström S, Åström J, Bøhn K, Gjershaug JO, Staverløkk A, Ødegaard F (2014) Butterflies and bumblebees as biodiversity indicators in Nature index for Norway. Summary of the activity in 2014. NINA Rapport 1098. Trondheim, Norway.

Berg Å, Ahrné K, Öckinger E, Svensson R, Söderström B (2011) Butterfly distribution and abundance is affected by variation in the Swedish forest-farmland landscape. Biological Conservation 144: 2819-2831. doi: 10.1016/j.biocon.2011.07.035

Bergman KO, Askling J, Ekberg O, Ignell H, Wahlman H, Milberg P (2004) Landscape effects on butterfly assemblages in an agricultural region. Ecography 27: 619-628. doi: 10.1111/j.0906-7590.2004.03906.x

Betzholtz P-E, Pettersson LB, Ryrholm N, Franzén M (2013) With that diet, you will go far: trait-based analysis reveals a link between rapid range expansion and a nitrogen-favoured diet. Proceedings of the Royal Society B: Biological Sciences 280: 2012-2305. doi: 10.1098/rspb.2012.2305

Botham MS, Brereton TM, Middlebrook I, Randle Z, Roy DB (2013) United Kingdom Butterfly Monitoring Scheme report for 2012. Centre for Ecology \& Hydrology, Wallingford, UK.

Brereton TM, Cruickshanks KL, Risely K, Noble DG, Roy DB (2011) Developing and launching a wider countryside butterfly survey across the United Kingdom. Journal of Insect Conservation 15: 279-290. doi: 10.1007/s10841-010-9345-8

Cousins SAO, Auffret AG, Lindgren J, Trank L (2015) Regional-scale land-cover change during the 20th century and its consequences for biodiversity. Ambio 44: S17-S27. doi: 10.1007/s13280-014-0585-9

Davey CM, Devictor V, Jonzén N, Lindström Å, Smith HG (2013) Impact of climate change on communities: revealing species' contribution. Journal of Animal Ecology 82: 551-561. doi: 10.1111/1365-2656.12035

Dennis RLH, Shreeve TG, Isaac NJB, Roy DB, Hardy PB, Fox R, Asher J (2006) The effects of visual apparency on bias in butterfly recording and monitoring. Biological Conservation 128: 486-492. doi: 10.1016/j.biocon.2005.10.015 
Dennis RLH, Sparks TH, Hardy PB (1999) Bias in butterfly distribution maps: the effects of sampling effort. Journal of Insect Conservation 3: 33-42. doi: 10.1023/A:1009678422145

Dennis RLH, Thomas CD (2000) Bias in butterfly distribution maps: the influence of hot spots and recorder's home range. Journal of Insect Conservation 4: 73-77. doi: 10.1023/A:1009690919835

Dover JW, Sparks TH, Greatorex-Davies JN (1997) The importance of shelter for butterflies in open landscapes. Journal of Insect Conservation 1: 89-97. doi: 10.1023/A:1018487127174

Dover JW, Spencer S, Collins S, Hadjigeorgiou I, Rescia A (2011) Grassland butterflies and low intensity farming in Europe. Journal of Insect Conservation 15: 129-137. doi: 10.1007/ s10841-010-9332-0

Eilers S, Pettersson LB, Öckinger E (2013) Micro-climate determines oviposition site selection and abundance in the butterfly Pyrgus armoricanus at its northern range margin. Ecological Entomology 38: 183-192. doi: 10.1111/een.12008

Ekroos J, Heliola J, Kuussaari M (2010) Homogenization of lepidopteran communities in intensively cultivated agricultural landscapes. Journal of Applied Ecology 47: 459-467. doi: 10.1111/j.1365-2664.2009.01767.x

Eliasson CU, Ryrholm N, Holmer M, Jilg K, Gärdenfors U (2005) Nationalnyckeln till Sveriges flora och fauna. Fjärilar: Dagfärilar. Hesperiidae - Nymphalidae. SLU, Uppsala.

Green M, Lindström $\AA$ (2015) Monitoring population changes of birds in Sweden. Annual report for 2014. Department of Biology, Lund University, Lund.

Greenwood JJD, Baillie SR, Gregory RD, Peach WJ, Fuller RJ (1995) Some new approaches to conservation monitoring of British breeding birds. Ibis 137: S16-S28. doi: 10.1111/j.1474919X.1995.tb08437.x

Heliölä J, Kuussaari M, Niininen I (2013) Results of the butterfly monitoring scheme in Finnish agricultural landscapes for the year 2012. Baptria 38: 38-45.

Jonason D, Milberg P, Bergman KO (2010) Monitoring of butterflies within a landscape context in south-eastern Sweden. Journal for Nature Conservation 18: 22-33. doi: 10.1016/j. jnc.2009.02.001

Kéry M, Plattner M (2007) Species richness estimation and determinants of species detectability in butterfly monitoring programmes. Ecological Entomology 32: 53-61. doi: 10.1111/j.1365-2311.2006.00841.x

Konvicka M, Benes J, Cizek O, Kopecek F, Konvicka O, Vitaz L (2008) How too much care kills species: Grassland reserves, agri-environmental schemes and extinction of Colias myrmidone (Lepidoptera : Pieridae) from its former stronghold. Journal of Insect Conservation 12: 519-525. doi: 10.1007/s10841-007-9092-7

Kühn E, Musche M, Harpke A, Feldmann R, Metzler B, Hirneisen N, Settele J (2012) Tagfalter-Monitoring Deutschland Jahresbericht 2011. Helmholtz-Zentrum für Umweltforschung - UFZ, Halle, Germany.

Lang A, Buhler C (2012) Estimation of required sampling effort for monitoring the possible effects of transgenic crops on butterflies: Lessons from long-term monitoring schemes in Switzerland. Ecological Indicators 13: 29-36. doi: 10.1016/j.ecolind.2011.05.004

Lehikoinen A (2013) Climate change, phenology and species detectability in a monitoring scheme. Population Ecology 55: 315-323. doi: 10.1007/s10144-012-0359-9 
Lindenmayer DB, Likens GE (2009) Adaptive monitoring: a new paradigm for long-term research and monitoring. Trends in Ecology \& Evolution 24: 482-486. doi: 10.1016/j. tree.2009.03.005

Magurran AE (2004) Measuring biological diversity. Blackwell Publishing, Oxford, UK.

New TR (1997) Are Lepidoptera an effective 'umbrella group' for biodiversity conservation? Journal of Insect Conservation 1: 5-12. doi: 10.1023/A:1018433406701

Nilsson SG, Franzén M, Pettersson LB (2013) Land-use changes, farm management and the decline of butterflies associated with semi-natural grasslands in southern Sweden. Nature Conservation 6: 31-48. doi: 10.3897/natureconservation.6.5205

Öckinger E, Eriksson AK, Smith HG (2006) Effects of grassland abandonment, restoration and management on butterflies and vascular plants. Biological Conservation 133: 291-300. doi: 10.1016/j.biocon.2006.06.009

Pettersson LB, Harris S, Mellbrand K (2011) Swedish Butterfly Monitoring Scheme, annual report for 2010. Department of Biology, Lund University, Lund.

Pollard E, Yates TJ (1993) Monitoring butterflies for ecology and conservation: the British butterfly monitoring scheme. Conservation Biology Series No 1. Chapman \& Hall, London, UK.

QGIS Development Team (2016) QGIS Geographic Information System. Open Source Geospatial Foundation Project. http://qgis.osgeo.org

Roy DB, Ploquin EF, Randle Z, Risely K, Botham MS, Middlebrook I, Noble D, Cruickshanks K, Freeman SN, Brereton TM (2015) Comparison of trends in butterfly populations between monitoring schemes. Journal of Insect Conservation 19: 313-324. doi: 10.1007/ s10841-014-9739-0

Roy DB, Rothery P, Brereton T (2007) Reduced-effort schemes for monitoring butterfly populations. Journal of Applied Ecology 44: 993-1000. doi: 10.1111/j.1365-2664.2007.01340.x

Söderström B (2006) Svenska färilar - en fälthandbok. Albert Bonniers Förlag, Stockholm.

Swedish Environmental Protection Agency (2014) Svenska Marktäckedata, Produktbeskrivning. Utgåva 1.1. http://mdp.vic-metria.nu/miljodataportalen/

Thomas JA, Telfer MG, Roy DB, Preston CD, Greenwood JJD, Asher J, Fox R, Clarke RT, Lawton JH (2004) Comparative losses of British butterflies, birds, and plants and the global extinction crisis. Science 303: 1879-1881. doi: 10.1126/science.1095046

Thomas JA (2005) Monitoring change in the abundance and distribution of insects using butterflies and other indicator groups. Philosophical Transactions of the Royal Society BBiological Sciences 360: 339-357. doi: 10.1098/rstb.2004.1585

Tolman T (2001) Photographic guide to the butterflies of Britain and Europe. Oxford University Press, Oxford.

Wallisdevries MF, van Swaay CAM (2006) Global warming and excess nitrogen may induce butterfly decline by microclimatic cooling. Global Change Biology 12: 1620-1626. doi: 10.1111/j.1365-2486.2006.01202.x

Van Dyck H, van Strien AJ, Maes D, van Swaay CAM (2009) Declines in common, widespread butterflies in a landscape under intense human use. Conservation Biology 23: 957-965. doi: 10.1111/j.1523-1739.2009.01175.x

van Swaay C, Warren M, Lois G (2006) Biotope use and trends of European butterflies. Journal of Insect Conservation 10: 189-209. doi: 10.1007/s10841-006-6293-4 
van Swaay CAM, Nowicki P, Settele J, van Strien AJ (2008) Butterfly monitoring in Europe: methods, applications and perspectives. Biodiversity and Conservation 17: 3455-3469. doi: 10.1007/s10531-008-9491-4

van Swaay CAM, van Strien AJ, Aghababyan K, Åström S, Botham M, Brereton T, Chambers $\mathrm{P}$, Collins S, Domènech Ferrés M, Escobés R, Fernández-García JM, Fontaine B, Goloshchapova S, Gracianteparaluceta A, Harpke A, Heliölä J, Khanamirian G, Julliard R, Kühn E, Lang A, Leopold P, Loos J, Maes D, Mestdagh X, Monasterio Y, Munguira ML, Murray T, Musche M, Óunap E, Pettersson LB, Popoff S, Prokofev I, Roth T, Roy D, Settele J, Stefanescu C, Švitra G, Teixeira SM, Tiitsaar A, Verovnik R, Warren MS (2015) The European Butterfly Indicator for Grassland species: 1990-2013. Report VS2015.009. De Vlinderstichting, Wageningen, NL.

van Swaay CAM, Warren MS (2012) Developing butterflies as indicators in Europe: current situation and future options. Report VS2012.012. De Vlinderstichting, Wageningen, NL. Zar JH (1999) Biostatistical analysis, $4^{\text {th }}$ edn. Prentice-Hall International, London, UK.

\section{Appendix}

Table SI. Geographical coordinates (Swedish grid, RT 902.5 gon V) for butterfly monitoring sites.

\begin{tabular}{c|c|c|c|c|c}
\hline Site & Municipality & Region & Recording & Latitude (N) & Longitude (E) \\
\hline Hyby & Svedala & Scania & $2010-06-17$ & $55.5595^{\circ}$ & $13.2235^{\circ}$ \\
\hline Tjörnarp & Höör & Scania & $2010-06-24$ & $56.0170^{\circ}$ & $13.5922^{\circ}$ \\
\hline Slätteberga & Tomelilla & Scania & $2010-06-29$ & $55.7985^{\circ}$ & $14.0016^{\circ}$ \\
\hline Kongaö & Svalöv & Scania & $2010-07-07$ & $56.0089^{\circ}$ & $13.1913^{\circ}$ \\
\hline Sundom & Luleå & Norrbotten & $2010-07-20$ & $65.7750^{\circ}$ & $22.0709^{\circ}$ \\
\hline Rosfors & Piteå & Norrbotten & $2010-07-23$ & $65.5780^{\circ}$ & $21.4869^{\circ}$ \\
\hline Långberget & Boden & Norrbotten & $2010-07-24$ & $65.8021^{\circ}$ & $21.5372^{\circ}$ \\
\hline Bergnäset & Luleå & Norrbotten & $2010-07-28$ & $65.5614^{\circ}$ & $22.0342^{\circ}$ \\
\hline
\end{tabular}


Table S2. Butterfly species recorded in each region.

\begin{tabular}{|c|c|c|c|c|}
\hline English name & Scientific name & Scania & Norrbotten & Total \\
\hline Large Skipper & Ochlodes sylvanus & 59 & 4 & 63 \\
\hline Black-veined White & Aporia crataegi & 2 & 0 & 2 \\
\hline Large White & Pieris brassicae & 2 & 0 & 2 \\
\hline Green-veined White & Pieris napi & 7 & 2 & 9 \\
\hline Moorland Clouded Yellow & Colias palaeno & 0 & 1 & 1 \\
\hline Brimstone & Gonepteryx rhamni & 6 & 1 & 7 \\
\hline Idas Blue & Plebejus idas & 0 & 10 & 10 \\
\hline Cranberry Blue & Plebejus optilete & 24 & 12 & 36 \\
\hline Silvery Argus & Aricia nicias & 0 & 10 & 10 \\
\hline Amanda's Blue & Polyommatus amandus & 2 & 1 & 3 \\
\hline Common Blue & Polyommatus icarus & 6 & 2 & 8 \\
\hline Scarce Copper & Lycaena virgaureae & 0 & 49 & 49 \\
\hline Green Hairstreak & Callophrys rubi & 1 & 0 & 1 \\
\hline Dark Green Fritillary & Argynnis aglaja & 0 & 3 & 3 \\
\hline High Brown Fritillary & Argynnis adippe & 0 & 1 & 1 \\
\hline Lesser Marbled Fritillary & Brenthis ino & 10 & 9 & 19 \\
\hline Pearl-bordered Fritillary & Boloria euphrosyne & 1 & 0 & 1 \\
\hline Small Pearl-bordered Fritillary & Boloria selene & 16 & 1 & 17 \\
\hline Map Butterfly & Araschnia levana & 2 & 0 & 2 \\
\hline Red Admiral & Vanessa atalanta & 1 & 0 & 1 \\
\hline Peacock Butterfly & Aglais io & 6 & 0 & 6 \\
\hline Small Tortoiseshell & Aglais urticae & 7 & 49 & 56 \\
\hline Heath Fritillary & Melitaea athalia & 2 & 0 & 2 \\
\hline Speckled Wood & Pararge aegeria & 1 & 0 & 1 \\
\hline Wall Brown & Lasiommata megera & 1 & 0 & 1 \\
\hline Large Wall Brown & Lasiommata maera & 1 & 0 & 1 \\
\hline Small Heath & Coenonympha pamphilus & 16 & 0 & 16 \\
\hline Ringlet & Aphantopus hyperantus & 51 & 0 & 51 \\
\hline Arran Brown & Erebia ligea & 0 & 69 & 69 \\
\hline Unknown Black & & 1 & 0 & 1 \\
\hline Unknown White & & 7 & 2 & 9 \\
\hline Unknown Blue & & 6 & 8 & 14 \\
\hline \multirow[t]{3}{*}{ Unknown Orange } & & 12 & 6 & 18 \\
\hline & Total number of individuals: & 250 & 240 & 490 \\
\hline & Total number of species: & 22 & 16 & 29 \\
\hline
\end{tabular}




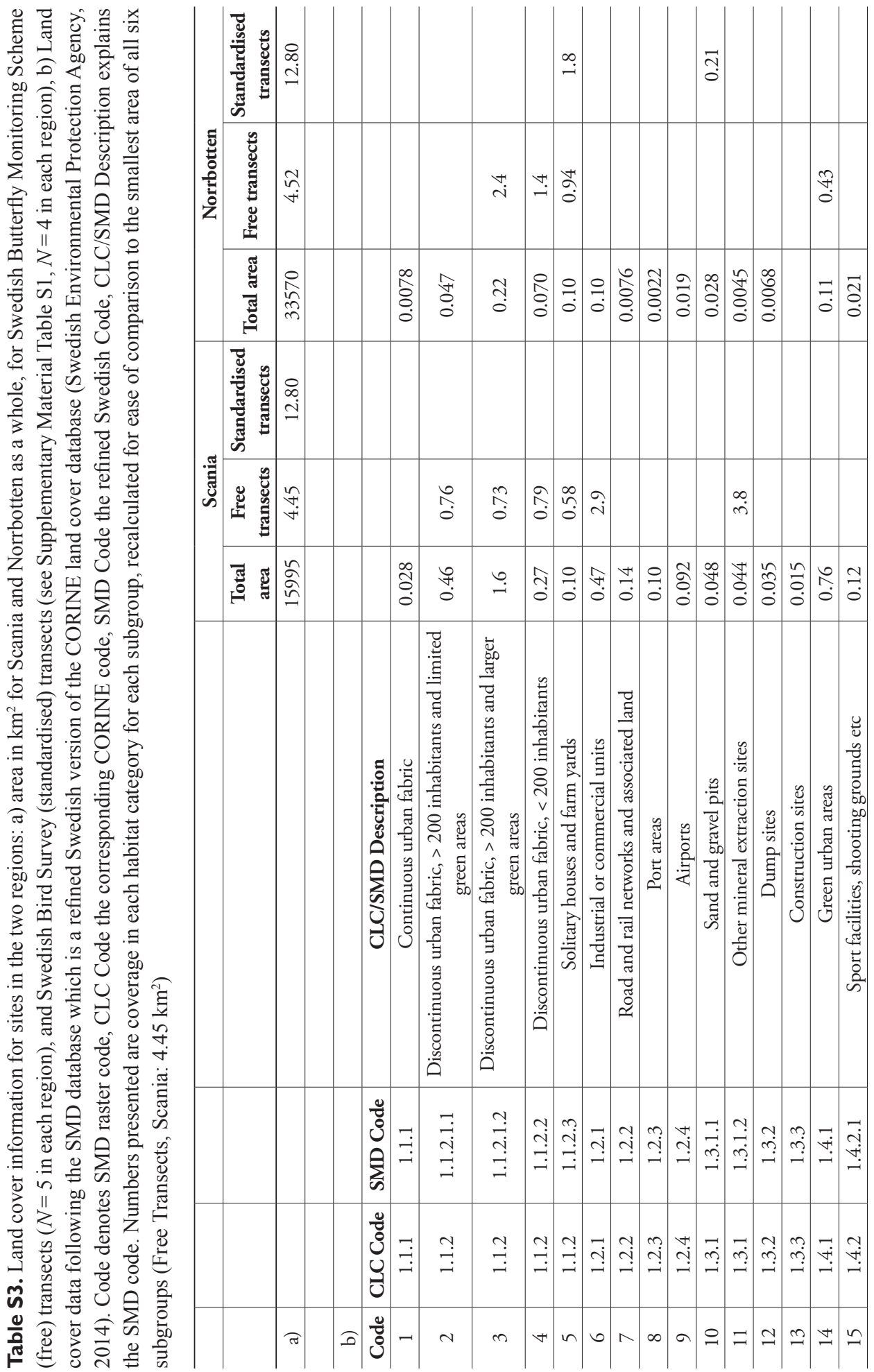




\begin{tabular}{|c|c|c|c|c|c|c|c|c|c|c|c|c|c|c|c|c|c|c|c|c|c|c|c|c|}
\hline 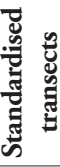 & & & & & $\stackrel{\circ}{\circ}$ & & $\hat{\tilde{o}}$ & $\stackrel{o}{i}$ & \begin{tabular}{l}
0 \\
\multirow{0}{0}{}
\end{tabular} & $\begin{array}{l}\ddot{n} \\
\dot{n}\end{array}$ & $\triangle$ & $\stackrel{\infty}{\rightarrow}$. & $\stackrel{?}{-}$ & $\vec{i}$ & $\dot{0}$ & & & & & & $\begin{array}{c}\infty \\
\infty \\
\infty\end{array}$ & & $\stackrel{\vartheta}{\circ}$ & \\
\hline 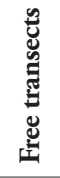 & & & & & $\beth$ & & $\stackrel{\infty}{i}$ & $\stackrel{\forall}{\dot{m}}$ & $\stackrel{m}{m}$ & $\begin{array}{l}\tilde{n} \\
\tilde{0}\end{array}$ & 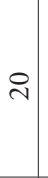 & $\approx$ & \begin{tabular}{l}
\multirow{2}{*}{} \\
0 \\
0
\end{tabular} & $\stackrel{\overbrace{}}{\lessgtr}$ & $=\left(\begin{array}{l}\infty \\
0\end{array}\right.$ & & & & $\begin{array}{l}\stackrel{7}{0} \\
\stackrel{0}{0} \\
\end{array}$ & $\left.\begin{array}{lll}\infty & \\
0 \\
0\end{array}\right]$ & \pm & & 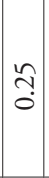 & I \\
\hline 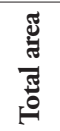 & $\begin{array}{l}n \\
\overline{8} \\
\dot{0}\end{array}$ & $\stackrel{\circ}{0}$ & $\begin{array}{l}2 \\
\hat{\delta} \\
0 \\
0\end{array}$ & $\vec{\sigma}$ & 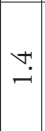 & $\begin{array}{c}1 \\
8 \\
0 \\
0\end{array}$ & $\stackrel{0}{-}$ & $\vec{i}$ & $\stackrel{+}{\hat{0}}$ & $\begin{array}{l}\dot{0} \\
\dot{r}\end{array}$ & $\stackrel{\circ}{-}$ & $\therefore$ & $\begin{array}{l}\bullet \\
\dot{\sim}\end{array}$ & $\begin{array}{lll}n & \\
0 \\
0\end{array}$ & 工 & : & $\begin{array}{l}2 \\
0 \\
0 \\
0 \\
0\end{array}$ & $\begin{array}{l}n \\
0 \\
0 \\
0\end{array}$ & $\stackrel{m}{0}$ & అ̧: & $=\tilde{\delta}$ & $\stackrel{m}{0}$ & 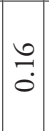 & $\stackrel{\text { r }}{-}$ \\
\hline
\end{tabular}

\begin{tabular}{|c|c|c|c|c|c|c|c|c|c|c|c|c|c|c|c|c|c|c|c|c|c|}
\hline 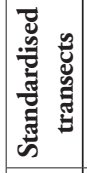 & & $\stackrel{\vec{r}}{\vec{r}}$ & $\stackrel{-}{-}$ & & 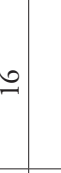 & $\underset{\infty}{+}$ & 우 & $\begin{array}{l}0 \\
i\end{array}$ & $\vec{m}$ & 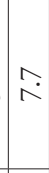 & $\stackrel{0}{\dot{r}}$ & సे & $\begin{array}{l}n \\
0 \\
0\end{array}$ & & & $\sqrt[8]{6}$ & $\begin{array}{ccc}n & n \\
0 & n\end{array}$ & & & & $\begin{array}{l}\text { ठे } \\
0 \\
0\end{array}$ \\
\hline 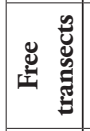 & & & $\vec{m}$ & & $\stackrel{f}{F}$ & $\Xi$ & $\infty$ & & $\stackrel{?}{-}$ & $\stackrel{\leftrightarrow}{\sim}$ & & $\hat{i}$ & & & & I & \begin{tabular}{l}
$y$ \\
\cline { 1 - 1 }
\end{tabular} & & & & \\
\hline ت్ & 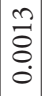 & 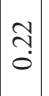 & \begin{tabular}{|l|l}
1 & \\
0 & \\
0 & \\
0 &
\end{tabular} & $\begin{array}{l}\stackrel{+}{a} \\
\grave{0} \\
\dot{0}\end{array}$ & $m \frac{n}{0}$ & $\tilde{n}$ & $\stackrel{\wedge}{\infty}$ & $\vec{\jmath}$ & $\stackrel{m}{\dot{m}}$ & $\widehat{\sigma}$ & ฯ & 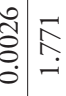 & $\stackrel{ }{0}$ & $\begin{array}{l}\tilde{Z} \\
\tilde{O} \\
0 \\
0\end{array}$ & $\left|\begin{array}{l}\infty \\
\tilde{O} \\
0 \\
0\end{array}\right|$ & $=$ & - & $\dot{j} \underset{0}{\stackrel{O}{0}}$ & $\begin{array}{l}0 \\
0 \\
0 \\
0 \\
\end{array}$ & $\stackrel{1}{\circ}$ & $\begin{array}{l}\stackrel{a}{+} \\
\vdots \\
0\end{array}$ \\
\hline
\end{tabular}

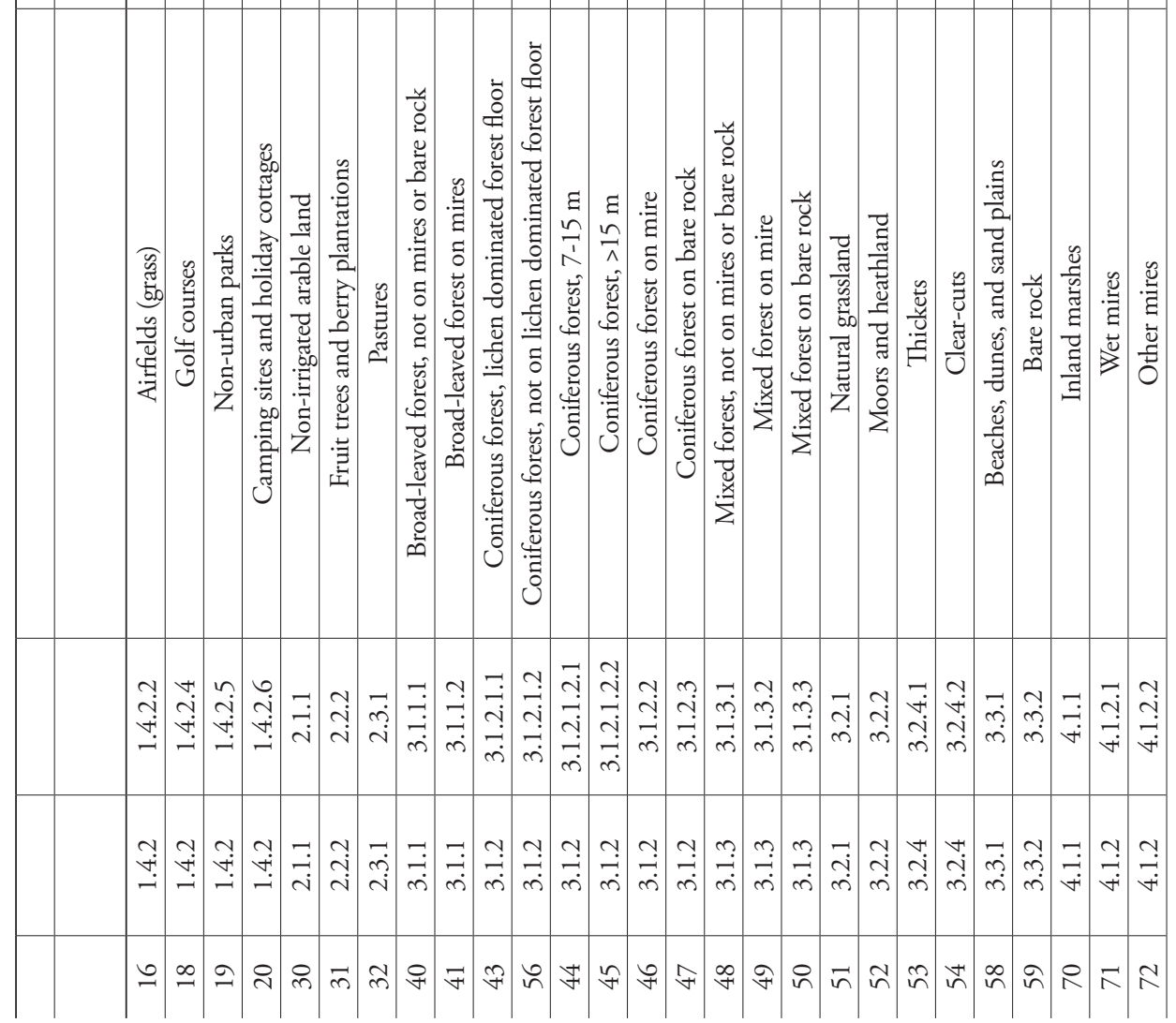




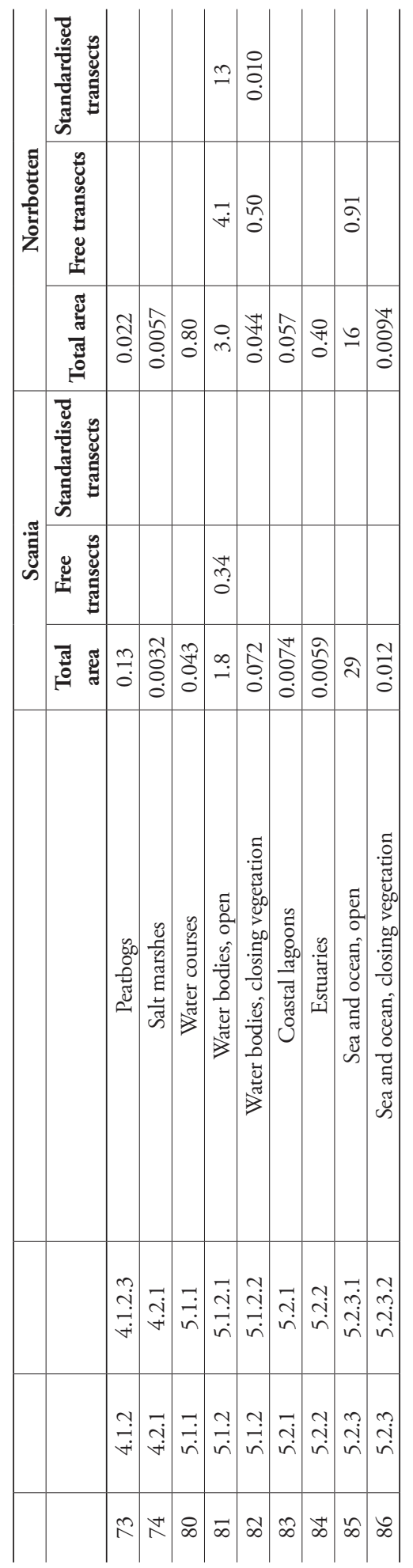

